\title{
HUBUNGAN PERSONAL HYGIENE DENGAN PENYAKIT KECACINGAN PADA SISWA SDN 113 KUNGKAI BARU KABUPATEN SELUMA
}

\author{
Elsa Prihatin Sismi, Mely Gustina, Agus Widada \\ Politeknik Kesehatan Kementerian Kesehatan Bengkulu, Jurusan Kesehatan Lingkungan, \\ Jalan Indragiri Nomor 03 Padang Harapan Kota Bengkulu \\ jmkbengkulu@gmail.com
}

\begin{abstract}
Worm infection disease is a disease that is often overlooked because it does not directly cause death. One reason could be transmitted through soil, called nematoda bowels. Prevalence of worm infection Bengkulu province according to the city health departement Bengkulu 2010 was $18 \%-23 \%$ of cases occur in children of primary school age, New Kungkai village there are $41,9 \%$ of children were infected with intestinal worms. Based on the initial survey dated 7 February 2015, the SDN 113 New Kungkai is one of the schools that still have a school yard in the form of soil moist, shaded by trees, poor environmental sanitation situation maintained that there are many scattered garbage. By mark worms $80 \%$ of students who are anemic as lethargy, pale face, weight loss, listlessness, lack of concentration studied, pale eyes, it is because there are many students who have not applied with good personal hygiene, such as not washing hands before eating cafeteria, student habits rarely cut nails, there is still a long nail black and the students still love playing ground with no wear good footwear when out to play and at school. The purpose of this study was to determine the relationship between personal hygiene worm disease in SDN 113 New Kungkai Seluma. Design study used cross sectional. The study sampel was grade 1 to 6 , amounting to 27 people. Sampling technique used is propotional random sampling. Data were analyzed with univariate an bivariate (square test with a $P$ value $\alpha=0,05$ ) of 72 respondents in getting results $49(68,1 \%)$ of respondents who have poor personal hygiene and $43(59,7 \%)$ respondents had positive worm. Bivariate analysis results showed that $P=0,001<\alpha=0,05$ values showed no relatoinship between personal hygiene with worming with OR $95 \% \mathrm{CI}=$ 6,330 . Noteworthy health education to the students about the worms and the importance of healthy behavior and clean.
\end{abstract}

Keywords : Personal hygiene, worm disease.

Abstrak: Penyakit infeksi kecacingan merupakan penyakit yang sering terabaikan dan akan
menyebabkan kematian secara tidak langsung. Salah satu penyebabnya dapat ditularkan
melalui tanah, yang disebut nematoda usus. Prevalensi kasus kecacingan Provinsi Bengkulu
menurut Dinas Kesehatan Kota Bengkulu tahun 2010 adalah $18 \%$ - $23 \%$ kasus terbanyak
terjadi pada anak usia sekolah dasar, desa Kungkai Baru terdapat $41,9 \%$ anak yang terinfeksi
kecacingan. Berdasarkan survei awal tanggal 7 Februari 2015 , SDN 113 Kungkai merupakan
salah satu sekolah yang masih memiliki halaman sekolah yang berbentuk tanah, lembab,
teduh dengan pohon-pohon, keadaan sanitasi lingkungan yang kurang terawat yaitu masih
banyak sampah berserakan. Berdasarkan tanda kecacingan $80 \%$ siswa yang menglami anemia
seperti lesu, wajah pucat, berat badan menurun, tidak bergairah, konsentrasi belajar kurang,
mata pucat, hal ini disebabkan masih banyaknya siswa yang belum menerapkan personal
hygiene dengan baik, seperti tidak mencuci tangan sebelum makan dikantin, kebiasaan siswa
yang jarang memotong kuku, kuku masih ada yang panjang berwarna hitam dan siswa masih
suka bermain tanah dengan tidak memakai alas kaki baik pada saat keluar main dan pada saat
pulang sekolah. Tujuan penelitian ini adalah untuk mengetahui hubungan antara personal
hygiene dengan penyakit kecacingan di SDN 113 Kungkai Baru Kabupaten Seluma. Desain
penelitian yang digunakan potong silang. Sampel penelitian ini adalah siswa kelas 1 sampai 6
yang berjumlah 72 orang. Tekhnik sampel yang digunakan adalah Propotional random
sampling. Data dianalisis dengan univariat dan bivariat (uji Chi square dengan P value $\alpha=$
0,05), dari 72 responden didapatkan hasil 49 (68,1 \%) responden yang memiliki personal 
hygiene yang kurang baik dan $43(59,7 \%)$ responden mengalami positif kecacingan. Hasil analisis bivariat menunjukkan bahwa nilai $\mathrm{p}=0,001<\alpha=0,05$ menunjukkan ada hubungan antara personal hygiene dengan penyakit kecacingan dengan OR $95 \% \mathrm{CI}=6,330$ sehingga perlu dilakukan penyuluhan kesehatan kepada siswa tentang kecacingan dan pentingnya perilaku hidup sehat dan bersih.

Kata kunci : personal hygiene, penyakit kecacingan

Kesehatan merupakan anugrah yang berharga sebagai investasi jangka panjang untuk mempertahankan kehidupan manusia dan menjadi salah satu modal dasar dalam peningkatan kualitas sumber daya manusia (SDM) yang dapat menunjang keberhasilan pembangunan bangsa. Maka diperlukan pembangunan bangsa, kesehatan secara menyeluruh dan berkesinambungan (Depkes RI, 2007).

Cacing merupakan salah satu parasit pada manusia dan hewan yang sifatnya merugikan dimana manusia merupakan hospes untuk beberapa jenis cacing yang termasuk Nematoda usus. Sebagian besar Nematoda ini masih merupakan masalah kesehatan masyarakat di Indonesia. Diantara Nematoda usus terdapat sejumlah spesies yang penularannya melalui tanah (Soil Transmitted Helmints) diantaranya yang sering adalah Ascaris lumbricoides, Necator americanus, dan Trichura trichuris (Gandahusada, 2006).

Penelitian ini dilakukan di Laboratorium Klinik Akademi Analis Kesehatan Bengkulu untuk pemeriksaan feses yang dilakukan pada tanggal 13 dan 14 Mei 2015. Adapun penelitian ini adalah untuk mengidentifikasi telur cacing Nematoda usus pada feses. Pada tanggal 13 dan 14 Mei 2015 dilakukan pengambilan sampel feses pada siswa SD Negeri 113 Kungkai Baru Kabupaten Seluma. Sampel yang diambil adalah feses kelas I yang berjumlah 12 orang, pada kelas II berjumlah 14 orang, kelas III berjumlah 13 orang, kelas IV berjumlah 10 orang, kelas V berjumlah 11 orang, kelas VI berjumlah 12 orang. Kemudian sampel langsung dibawah ke Laboratorium Klinik Akademi Analis Kesehatan Bengkulu untuk diperiksa. Penelitian ini bertujuan untuk mengetahui hubungan personal hygiene dengan penyakit kecacingan pada siswa SD Negeri 113 Kungkai Baru Kabupaten Seluma. Sampel dalam penelitian ini adalah anak-anak sekolah kelas 1 sampai 6 di SD Negeri 113
Kungkai Baru Kabupaten Seluma yang berjumlah 72 orang.

\section{BAHAN DAN CARA KERJA}

Jenis penelitian yang digunakan dalam penelitian ini adalahpotong silang. Sampel penelitian ini adalah siswa kelas 1 sampai 6 yang berjumlah 72 orang. Tekhnik sampel yang digunakan adalah propotional random sampling. Pengumpulan data yang dilakukan dengan cara memberikan pertanyaan kepada responden yang disediakan dilembar kuesioner dan pemeriksaan telur cacing pada feses. Cara pengumpulan sampel ini menggunakan tekhnik pengambilan dengan propotional random sampling. Setelah data terkumpul kemudian dikelompokkan ke dalam masing-masing veriabel sesuai keperluan dan dilakukan pengkodean, kemudian dilakukan entry data dan dilakukan pengecekkan kebenaran data. Setelah itu dengan menggunakan komputer, data tersebut diolah dan dianalisa secara univariat, yaitu distribusi frekuensi va-riabel penelitian serta analisa bivariat dengan menggunakan uji chi square.Data dianalisis dengan univariat dan bivariat

\section{HASIL}

\section{Analisis Univariat}

Analisis ini dilakukan untuk melihat distribusi frekuensi dari personal hygiene pada siswa SD Negeri 113 Kungkai Baru Kabupaten Seluma, sehingga dapat menggambarkan tentang kondisi aktual responden dalam menjawab pertanyaan kuesioner penelitian terhadap masing-masing variabel penelitian.

Tabel 1 menunjukkan bahwa dari 72 siswa SD Negeri 113 Kungkai Baru Kabupaten Seluma sebagia besar dari responden 49 $(68,1 \%)$ memiliki personal hygiene kurang baik. Dan menunjukkan bahwa dari 72 siswa SDN 113 Kungkai Baru Kabupaten Seluma 
sebagian besar dari responden 43 (59,7\%) siswa yang mengalami positif kecacingan.

Tabel 1 Distribusi Frekuensi Responden Berdasarkan Personal Hygiene dan penyakit kecacingan pada Siswa SDN 113 Kungkai Baru Kabupaten Seluma

\begin{tabular}{lcc}
\hline Variabel & $\begin{array}{c}\text { Frekuensi } \\
\text { N=72 }\end{array}$ & $\begin{array}{c}\text { Persentase } \\
(\mathbf{1 0 0 \% )}\end{array}$ \\
\hline Personal hygiene & & \\
Baik & 23 & 31,9 \\
Kurang baik & 49 & 68,1 \\
Penyakit kecacingan & & \\
(+) kecacingan & 43 & 59,7 \\
(-) kecacingan & 29 & 40,3 \\
\hline
\end{tabular}

\section{Analisis Bivariat}

Analisis ini dilakukan untuk mengetahui hubungan antara personal hygiene dengan kejadian kecacingan di SD Negeri 113 Kungkai Baru Kabupaten Seluma, hasilnya seperti terlihat pada tabel berikut :

Tabel 2 Hubungan Personal Hygiene Dengan Penyakit Kecacingan pada siswa SD Negeri 113 Kungkai Baru Kabupaten Seluma

\begin{tabular}{lccccccccc}
\hline \multirow{2}{*}{$\begin{array}{c}\text { Personal } \\
\text { hygiene }\end{array}$} & \multicolumn{4}{c}{$\begin{array}{c}\text { Penyakit } \\
\text { kecacingan }\end{array}$} & Total & OR $\begin{array}{c}\mathbf{P} \\
\text { value }\end{array}$ \\
\cline { 2 - 5 } & $\mathbf{( + )}$ & \multicolumn{1}{c}{$(-)$} & & & & \\
\hline Kurang baik & 36 & 73,5 & 13 & 26,5 & 49 & 100 & 6,330 & 0,001 \\
Baik & 7 & 30,4 & 16 & 69,6 & 23 & 100 & & \\
\hline
\end{tabular}

Berdasarkan tabel 4.3 terlihat bahwa dari 72 siswa SDN 113 Kungkai Baru Kabupaten Seluma sebagian besar dari responden 49 $(68,1 \%)$ yang memiliki personal hygiene kurang baik dan lebih dari sebagian responden $43(59,7 \%)$ mengalami positif kecacingan. Hasil analisis uji chie square diperoleh nilai $p$ $=0,001 \leq \alpha=0,05$ menunjukkan ada hubungan antara personal hygiene dengan penyakit kecacingan pada siswa SD Negeri 113 Kungkai Baru Kabupaten Seluma. OR (95 \% CI) 6,330 artinya resiko terinfeksi telur cacing nematoda usus cukup besar pada siswa SDN 113 Kungkai Baru Kabupaten Seluma.

\section{PEMBAHASAN}

\section{Personal hygiene}

Dari hasil penelitian yang sudah dilakukan menunjukkan bahwa sebagian besar responden $49(68,1 \%)$ yang memiliki personal hygiene kurang baik. Artinya siswa yang memiliki kebiasaan mencuci tangan tidak baik, jarang menggunakan alas kaki, dan jarang menggunting kuku lebih banyak dan akan beresiko terinfeksi kecacingan. Dalam hal ini, terdapat kecendrungan bahwa siswa yang mempunyai kebiasaan mencuci tangan yang baik, kebersihan kuku yang baik, dan menggunakan alas kaki saat beraktivitas, besar kemungkinannya untuk tidak terinfeksi kecacingan.

Kondisi SD Negeri 113 Kungkai Baru Kabupaten Seluma yang memiliki halaman dan lingkungan bermain dengan tanah yang lembab, gembur dan teduh merupakan tempat yang sangat cocok terhadap perkembangbiakan telur cacing nematoda usus. Selain itu kebiasaan siswanya yang tidak memakai alas kaki dan sering kontak dengan tanah mempermudahkan terjadinya kontaminasi telur cacing.

\section{Penyakit Kecacingan}

Dari hasil penelitian yang sudah dilakukan menunjukkan bahwa lebih dari sebagian responden $43(59,7 \%)$ siswa yang mengalami positif kecacingan. Dari hasil penelitian didapatkan kontaminasi telur cacing yang paling banyak yaitu 37 (51,9\%) responden yang terinfeksi telur cacing Ascaris lumbricoides dan $6(8,3 \%)$ responden yang terinfeksi telur cacing Trichuris trichura. Tingginya prevalensi telur cacing Ascaris lumbricoides kemungkinan karena adanya lapisan hialin yang tebal dan lapisan albuminoid yang berfungsi untuk melindungi isi telur dari kerusakan dan mempertahankan telur dari suhu yang panas dan kering. Sedangkan telur cacing parasit spesies lainnya tidak memiiki lapisan albuminoid. Selain itu juga karena jumlah telur yang dihasilkan oleh cacing Ascaris lumbricoides cukup bayak jika dibandingkan dengan spesies cacing parasit lainnya.

Menurut Agustin (2008), bahwa seekor telur cacing betina Ascaris lumbricoides dewasa akan menghasilkan \pm 200.000 butir telur perhari. Cacing betina Trichuris Trichura setiap hari butir telur menghasilkan 3.000-20.000 butir telur perhari. Sedangkan cacing betina Necator americanus menghasilakan 20.000 
butir telur perhari. Telur cacing Nematoda usus yang terdapat pada kuku didapatkan dari tanah yang mengandung telur cacing Nematoda usus dan menempel bersama kotoran kuku. Apabila siswa kontak dengan tanah yang terdapat telur cacing akan masuk kedalam kuku dan dapat tertelan pada saat makan apabila siswa tidak mencuci tangan sebelum makan dan sesudah BAB. Kuku yang panjang dan tidak terawat akan menjadi tempat melekatnya berbagai mikroorganisme seperti telur cacing Nematoda usus. Kebiasaan siswa yang sangat senang bermain dengan tanah, tidak memakai alas kaki serta tidak mencuci tangan sebelum makan dan sesudah BAB dapat menyebabkan telur cacing menempel pada kuku dan dapat tertelan ketika makan.

Menurut Pediarti (2006) bahwa infeksi penyakit cacingan pada anak-anak usia sekolah dapat mengganggu kemampuan belajarnya. Oleh karena itu pemantauan penyakit cacingan pada anak-anak usia sekolah perlu dilakukan dengan usaha pencegahan seperti mencuci tangan sebelum makan dan sesudah BAB, memotong kuku dengan rutin dan menjaga kebersihan individu. Kebiasaan mencuci tangan sebelum makan dengan menggunakan sabun mempunyai peranan penting dalam pencegahan infeksi kecacingan, karena lebih efektif menghilangkan kotoran dan debu secara mekanis dari permukaan kulit serta membersihkan kotoran dan telur cacing yang menempel pada permukaan kulit, kuku dan jari-jari pada kedua tangan.

\section{Hubungan Personal Hygiene dengan Penya- kit Kecacingan}

Dari hasil penelitian menunjukkan bahwa dari 72 siswa SDN 113 Kungkai Baru Kabupaten Seluma sebagian besar responden $49(68,1 \%)$ yang memiliki personal hygiene kurang baik dan lebih dari sebagian responden $43(59,7 \%)$ mengalami positif kecacingan yaitu $37(51,9 \%)$ responden yang terinfeksi telur cacing Ascaris lumbricoides dan $6(8,3 \%)$ responden yang terinfeksi telur cacing Trichuris trichura. Hal ini menunjukkan adanya hubungan personal hygiene dengan penyakit kecacingan pada siswa SD Negeri 113 Kungkai Baru Kabupaten Seluma dengan $p=0,001$.
Menurut Sumanto (2010) kunci pemberantasan kecacingan adalah memperbaiki hygiene dan sanitasi lingkungan sekolah. Faktor-faktor yang menyebabkan masih tingginya infeksi kecacingan adalah rendahnya tingkat sanitasi pribadi seperti kebiasaan mencuci tangan menggunakan sabun sebelum makan dan sesudah BAB, kebersihan kuku dan tidak menggunakan alas kaki saat beraktivitas.

Menurut Depkes (2006) hygiene perorangan sangat mempengaruhi kesehatan, terutama apabila seseorang memiliki kebiasaankebiasaan yang buruk seperti jarang memotong kuku, jarang menggunakan alas kaki saat beraktivitas di luar kelas dan juga berkebiasaan jarang mencuci tangan dengan sabun. Hal ini dapat memberikan peluang terhadap cacing untuk menyebar dan menginfeksi manusia. Hal-hal yang perlu diperhatikan oleh anakanak usia sekolah dasar yaitu : (1) Kebersihan kaki. Kebiasaan siswa pada saat siswa bermain diluar kelas jarang menggunakan alas kaki, hal ini memiliki resiko terinfeksinya telur cacing yang akan menginfeksi siswa melalui telapak kaki, maka dari itu sangatlah penting memekai alas kaki untuk menjaga agar telur/ larva cacing tidak masuk kedalam tubuh. Untuk mencegah infeksi cacingan pada anak, sebaiknya menjaga kebersihan diri anak terutama pada saat bermain di luar rumah. Tanah halaman yang ada di sekeliling sekolah merupakan tempat bermain paling disukai bagi anak, manakala pada tanah halaman tersebut banyak mengandung larva infektif cacing Ascaris lumbricoides, Trichuris trichura dan Necator americanus, peluang anak-anak untuk terinfeksi cacing akan semakin besar (Sumanto, 2010). Dalam penelitian ini tidak ditemukannya telur cacing tambang (Necator americanus) pada feses siswa SD Negeri 113 Kungkai Baru Kabupaten Seluma dalam pemeriksaan di laboratorium. (2) Kebersihan kuku. Jarang memotong kuku juga mempunyai hubungan terhadap infeksi kecacingan. Keadaan ini terjadi karena cacing dapat masuk kedalam tubuh melalui kuku kaki dan tangan, jelas bahwa yang jarang memotong kuku akan lebih banyak terjadi infeksi kecacingan karena telur atau larva cacing tertinggal didalam sela-sela kuku, kuku yang panjang bisa menjadi tempat 
mengendap kotoran yang mengandung telur atau larva cacing sehingga ketika makan, larva atau telur cacing akan ikut tertelan bersama makanan ditambah lagi anak tidak mencuci tangan sebelum makan. Cacing gelang (Ascaris lumbricoides) sangat mudah tertular melalui perantara kuku yang masuk ke mulut dan menginfeksi ke paru-paru. Maka dari itu kebersihan kuku dengan infestasi cacing usus harus tetap dijaga kebersihanya, sebagai tindakan pencegahan. Salah satu usaha pencegahan penyakit cacingan yaitu memelihara kebersihan diri dengan baik seperti memotong kuku. Kebersihan perorangan penting untuk pencegahan, kuku sebaiknya selalu dipotong pendek untuk menghindari penularan cacing dari tangan ke mulut (Yulianto, 2007). Dari hasil penelitian siswa SDN 113 Kungkai Baru Kabupaten Seluma 37 (51,9\%) siswa yang terinfeksi telur cacing Ascaris lumbricoides, hal ini menunjukka ada hubungan personal hygiene jarang memotong kuku menyebabkan terinfeksi telur cacing Ascaris lumbricoides pada siswa. (3) Kebersihan tangan. Jarang mencuci tangan pakai sabun juga erat kaitannya terinfeksi telur cacing, terutama telur cacing Ascaris lumbricoides. Hal ini terjadi karena penularan cacing bukan hanya melalui tangan yang masuk bersama makanan tetapi juga melalui pori-pori yang masuk melalui telapak kaki. Sedangkan pada responden yang mempunyai kebiasaan mencuci tangan yang kurang baik dan terdapat $43(59,7 \%)$ positif terinfeksi cacing. Dengan perantara tangan yang tidak di dicuci dengan sabun akibatnya telur cacing masih menempel di tangan dan

\section{DAFTAR RUJUKAN}

Agus, 2009. ParasitKedokteran di Tinjau dari Organ Tubuhyang Diserang. Jakarta: EGC

Agustin, 2008. Hubungan Infeksi dengan Pencemaran Tanah oleh Telur Cacing Soil Transmitted Helminths. Medan: Universitas Sumatra Utara

Arikunto, 2005. Metodologi Penelitian Kesehatan. Jakarta: Rineka Cipta.

Aru, 2006. Alur Diagnosis dan Pengobatannya di Indonesia. Jakarta: FKUI

Depkes RI, 2006. Pedoman Pengendalian Cacing. Permenkes RI Nomor 424/MENKES/SK/VI/2006. , 2007. Pedoman Pengendalian Cacingan . Direktorat Jendral P2PL. Jakarta kuku. Jarang mencuci tangan dengan sabun terutama sebelum makan dan sesudah $\mathrm{BAB}$ telur cacing lebih cepat tertular dan berkembang biak. Kecenderungan bahwa siswa yang punya kebiasaan mencuci tangan yang tidak baik lebih besar persentasenya terinfeksi cacing usus dibanding dengan siswa yang mempunyai kebiasaan mencuci tangan dengan baik, jadi harus tetap menjaga kebersihan diri untuk pencegahan. Kebiasaan mencuci tangan sebelum makan memakai air dan sabun mempunyai peranan penting dalam pencegahan infeksi kecacingan terutama Nematoda usus, karena dengan mencuci tangan dengan air dan sabun dapat lebih efektif menghilangkan kotoran dan debu secara mekanis dari permukaan kulit dan secara bermakna mengurangi jumlah mikroorganisme penyebab penyakit seperti virus, bakteri dan parasit lainnya pada kedua tangan. Salah satu usaha pencegahan penyakit cacing yaitu memelihara kebersihan diri dengan baik seperti mencuci tangan dan kaki untuk menghindari penularan cacing dari tangan ke mulut.

\section{KESIMPULAN}

Disimpulkan bahwa terdapat hubungan personal hygiene dengan penyakit kecacingan pada siswa SDN 113 Kungkai Baru Kabupaten Seluma. sehingga perlu dilakukan penyuluhan kesehatan kepada siswa tentang kecacingan dan pentingnya perilaku hidup sehat dan bersih.

Dinkes Kota Bengkulu, 2010. Data Survey Kecacingan: Prov Bengkulu

Gandahusada, 2006. Parasitologi Kedokteran. Jakarta : FKUI

Ibrahim, 2012. Ascariasis dan Trichuriasis Sebagai Faktor Penentu Kejadian Anemia Gizi Besi Anak SD Di Pemukiman Kumuh. Makasar

Irianto, 2009. Parasitologi. Berbagai Penyakit Yang Mempengaruhi Kesehatan Manusia. Bandung: CV.Yrama Widya.

Jalaludin, 2009. Pengaruh Sanitasi Lingkungan, Personal Hygiene dan Karakteristik Anak Terhadap Infeksi Kecacingan pada Murid Sekolah Dasar di Kecamatan Blang Mangat Kota Lhokseumawe. Medan: Universitas Sumatra Utara. 
Kepmenkes RI No.424. 2006. Pedoman Pengendalian Cacingan. Jakarta: Kepmenkes RI.

Kurt, 1999. Prinsip-Prinsip Ilmu Penyakit Dalam Volume. Jakarta: Penerbit Buku Kedokteran EGC

Laily, 2012. Personal Hygiene Konsep Proses dan Aplikasi dalam Praktik Keperawatan . Yogyakarta: Graha Ilmu

Maria, 2009. Konsep Personal Hygiene. Diakses pada tanggal 10 Februari 2015

http//naqsehat. Blogspot. Com/2010/02/ pemeriksaantinja.html.

Mardiana, 2008. Prevalensi cacing usus pada murid sekolah dasar wajib belajar pelayanan gerakan terpadu pengentasan kemiskinan daerah kumuh di wilayah DKI Jakarta. Jakarta: Jurnal Ekologi Kesehatan.

Notoatmodjo, 2010. Metodeologi Penelitian. Jakarta: Rineka Cipta.

Onggowaluyo JS, 2001. Parasitologi Medik I (Helmintologi). Pendekatan Aspek Indentifikasi Diagnosis dan Klinik: EGC.
Pediarti. S, 2006. Pengaruh Infeksi Cacing Usus yang Ditularkan melalui Tanah pada Pertumbuhan Fisik Anak Usia Sekolah Dasar. (Online),http://saripediarti.idai.or.id/pdfile/8-24.pdf. Diakses 05 Februari 2015

Safar, 2009. Protozologi, Entomologi, dan Helmintologi. Bandung: Yrama Widya

Sumanto, 2010. Faktor Risiko Infeksi Cacing Tambang Pada Anak Sekolah. Semarang: Universitas Diponegoro.

Sutanto, 2008. Perasitologi Kedokteran. Jakarta: Penerbit Buku FKUI. , 2009. Buku Ajar Parasitologi Kedokteran. Jakarta: FKUI.

WHO, 2011. Soil transmitted helminthes. Intestinal Worms (online), http://www.who.int/intestinal worms/en. Diakses 5 Februari 2015

Yulianto, 2007. Hubungan personal Higiene Dengan Kejadian Penyakit Cacingan. Semarang: Universitas Negeri Semarang.

Zulkoni, 2011. Parasitologi. Yogyakarta: Nuha Madika. 